Fakultas Komputer

ALMAUNAH Section 01

\title{
LANGKAH-LANGKAH PENGORGANISASIAN DATA SECARA TERSTRUKTUR \\ ALMAUNAH
}

195120034

Fakultas Komputer

Almaunah.student@umitra.ac.id

\begin{abstract}
Abstrack
Struktur data adalah mengorganisasikan data sedemikian rupa sehingga penerapan atau pemeliharaan menjadi lebih terstruktur sehingga data dapat diinterprestasikan sehingga data dapat dilaksankan pada data tersebut.

Turbo pascal adalah kumpulan intruksi atau perintah mempunyai urutan logika yg tepat untuk menyelsaikan suatu persoaalan atau sebuah aplikasi perangkat lunak yang terdiri dari compiler integrated development environment(IDE) bahasa programan pascal untuk sistem operasi $\mathrm{CP} / \mathrm{M}$, CP/M86, dan MS-DOS, yang dikembangkan oleh Borland pada masa kepemimpinan philippe kahn.

Algoritma adalah jantung semua program yang merupakan urutan langka sistematis untuk memecahkan masalah logika atau matematika.di dalam kehidupan sehari-hari sebenarnya kita menggunakan algoritma untuk menggunakan sesuatu.

Program adalah kata,ekspresi ,atau pertanyaan yang disusun dan dirangkai menjadi satu kesatuan prosedur, yang berupa urutan langkah, untuk menyelsaikan masalah yang diimplementasi dengan menggunakan bahasa pemograman sehingga dapat diesksekusi oleh komputer.
\end{abstract}




\author{
A. PENDAHULUAN \\ Membahas tentang Struktur data mengenai \\ Struktur Data Bahasa Program Turbo Pascal, \\ Algoritma dan Struktur Data, Karakteristik \\ Algoritma. Langkah-langkah pembuatan \\ program struktur Program Pascal dan jenis-jenis \\ Type Data. struktur data adalah penyimpanan, \\ penyusunan pengaturan data didalam media \\ penyimpanan komputer.
}

\section{Langkah-langkah pembuatan program}

- Mendefinisikan permasalahan

- Membuat rumusan untuk pemecahan masalah

- Implementasi \& coding

- Testing ( Menguji Coba) dan Membuat Dokumentasi

\section{Jenis-jenis Type Data}

- Type sederhana

- Type string

- Type terstruktur

- Type pointer

\section{B. PEMBAHASAN / STUDI KASUS}

Struktur data yang mengorganisasikan sedemikian rupa sehingga penerapan menjadi lebih terstruktur. Turbo pascal yaitu kumpulan intruksi yang disusun sehingga mempunyai urutan logika yang tepat untuk menyelsaikan persoaalan, program yang menurut bahasa intruksi atau perintah yang tersusun sehingga memiliki logika sehingga dapat menyelsikan persoalan. Algoritma merupakan urutan langka sistematis untuk menyelsaikan suatu masalah dengan usaha yang paling minimal, karakteristik algoritma; input,output,definite, efective,terminate.

\section{ID SECURITY}

QWTD4452377-ASP-5244166

\section{KESIMPULAN}

Struktur data befungsi mengorganisasikan data sehingga penerapan atau pemeliharaan logika program menjadi lebih terstruktur, pembaca juga dapat mengetahui langkahlangkah pembuatan program dan juga mengetahui type data. Algoritma yang jelas dapat menyelsaikan suatu masalah spesifik dengan usaha yang paling minimal. Program adalah yang disusun dan dirangkai menjadi satu kesatuan prosedur yang berupa urutan langkah, bahasa pemograman sehingga dapat diesksekusi komputer.

\section{E. DISKUSI}

Saya bersama teman saya yang bernama SELVIA CITRA DINIAS mendiskusikan tentang contoh ini dengan sangat baik dan mudah dipahami hasil dari diskusi dari materi ini kami data lebih memahami struktur data, program pascal dan algoritma. 
Fakultas Komputer

\section{Section 01}

\section{F. REFERENCE}

[ 1]O. M. Febriani and A. S. Putra, "Sistem Informasi Monitoring Inventori Barang Pada Balai Riset Standardisasi Industri Bandar Lampung," J. Inform., vol. 13, no. 1, pp. 90-98, 2014.

[2] A. S. Putra, "Paperplain: Execution Fundamental Create Application With Borland Delphi 7.0 University Of Mitra Indonesia," 2018.

[3] A. S. Putra, "2018 Artikel Struktur Data, Audit Dan Jaringan Komputer," 2018.

[4] A. S. Putra, "ALIAS MANAGER USED IN DATABASE DESKTOP STUDI CASE DB DEMOS."

[5] A. S. Putra, "COMPREHENSIVE SET OF PROFESSIONAL FOR DISTRIBUTE COMPUTING."

[6] A. S. Putra, "DATA ORIENTED RECOGNITION IN BORLAND DELPHI 7.0."

[7] A. S. Putra, "EMBARCADERO DELPHI XE 2 IN GPU-POWERED FIREMONKEY APPLICATION."

[8] A. S. Putra, "HAK ATAS KEKAYAAN INTELEKTUAL DALAM DUNIA TEKNOLOGY BERBASIS REVOLUSI INDUSTRI 4.0."

[9] A. S. Putra, "IMPLEMENTASI PERATURAN PERUNDANGAN UU. NO 31 TAHUN 2000 TENTANG DESAIN INDUSTRI BERBASIS INFORMATION TECHNOLOGY."

[10] A. S. Putra, "IMPLEMENTATION OF PARADOX DBASE."
ALMAUNAH

[11] A. S. Putra, "IMPLEMENTATION OF TRADE SECRET CASE STUDY SAMSUNG MOBILE PHONE."

[12] A. S. Putra, "IMPLEMENTATION PATENT FOR APPLICATION WEB BASED CASE STUDI WWW. PUBLIKLAMPUNG. COM."

[13] A. S. Putra, "IMPLEMENTATION SYSTEM FIRST TO INVENT IN DIGITALLY INDUSTRY."

[14] A. S. Putra, "MANUAL REPORT \& INTEGRATED DEVELOPMENT ENVIRONMENT BORLAND DELPHI 7.0."

[15] A. S. Putra, "PATENT AS RELEVAN SUPPORT RESEARCH."

[16] A. S. Putra, "PATENT FOR RESEARCH STUDY CASE OF APPLE. Inc."

[17] A. S. Putra, "PATENT PROTECTION FOR APPLICATION INVENT."

[18] A. S. Putra, "QUICK REPORT IN PROPERTY PROGRAMMING."

[19] A. S. Putra, "REVIEW CIRCUIT LAYOUT COMPONENT REQUIREMENT ON ASUS NOTEBOOK."

[20] A. S. Putra, "REVIEW TRADEMARK PATENT FOR INDUSTRIAL TECHNOLOGY BASED 4.0."

[21] A. S. Putra, "TOOLBAR COMPONENT PALLETTE IN OBJECT ORIENTED PROGRAMMING." 
[22] A. S. Putra, "WORKING DIRECTORY SET FOR PARADOX 7."

[23] A. S. Putra, "ZQUERY CONNECTION IMPLEMENTED PROGRAMMING STUDI CASE PT. BANK BCA Tbk."

[24] A. S. Putra, D. R. Aryanti, and I. Hartati, "Metode SAW (Simple Additive Weighting) sebagai Sistem Pendukung Keputusan Guru Berprestasi (Studi Kasus: SMK Global Surya)," in Prosiding Seminar Nasional Darmajaya, 2018, vol. 1, no. 1, pp. 85-97.

[25] A. S. Putra and O. M. Febriani, "Knowledge Management Online Application in PDAM Lampung Province," in Prosiding International conference on Information Technology and Business (ICITB), 2018, pp. 181-187.

[26] A. S. Putra, O. M. Febriani, and B. Bachry, "Implementasi Genetic Fuzzy System Untuk Mengidentifikasi Hasil Curian Kendaraan Bermotor Di Polda Lampung," SIMADA (Jurnal Sist. Inf. dan Manaj. Basis Data), vol. 1, no. 1, pp. 21-30, 2018.

[27] A. S. Putra, H. Sukri, and K. Zuhri, "Sistem Monitoring Realtime Jaringan Irigasi Desa (JIDES) Dengan Konsep Jaringan Sensor Nirkabel," IJEIS (Indonesian J. Electron. Instrum. Syst., vol. 8, no. 2, pp. 221-232.

[28] D. P. Sari, O. M. Febriani, and A. S. Putra, "Perancangan Sistem Informasi SDM Berprestasi pada SD Global Surya," in Prosiding Seminar Nasional Darmajaya, 2018, vol. 1, no. 1, pp. 289-294. 